\title{
Connessioni spazio_forma_struttura. Le teorie dell'abitare di Luigi Moretti, analisi e riconfigurazioni del quartiere Decima a Roma
}

\author{
Caterina Palestini
}

Abstract

Lo studio si muove nell'ambito delle connessioni ideologiche teorizzate da Luigi Moretti in campo artistico, architettonico e urbanistico. La capacità di ordire confronti culturali con l'arte, le correlazioni tra struttura e forma, le esperienze condotte negli anni sessanta dal geniale architetto costituiscono il fondamento su si sono cui articolate le indagini operative che innescano legami tra il disegno e le speculazioni teoriche da cui è derivato il moderno lessico dell'abitare. La contemporaneità della sperimentazione sulla progettazione parametrica, sulla configurazione della forma come insieme di relazioni, ha orientato la ricerca sulle tematiche proposte dal convegno. II contributo ripercorrendo gli assunti 'morettiani' si cala su un caso concreto: il quartiere INCIS Decima a Roma, esaminandolo attraverso analisi grafiche e riconfigurazioni digitali.

La metodologia d'indagine mette in evidenza le trasformazioni subite rispetto al progetto originario che lo proponeva come un modello funzionale e autosufficiente in linea con la nuova dimensione fisica della città moderna, in cui la varietà degli spazi urbani, il verde continuo, le strade, assumevano un ruolo decisivo in rapporto all'edificato. Analizzando la situazione attuale sono state indicate le criticità, gli elementi non realizzati, le aggiunte e le stratificazioni che nel tempo hanno snaturato i concetti iniziali. L'obiettivo è quello di recuperare l'essenza del progetto, del luogo che nonostante le trasformazioni preserva una forte identità, da ri-connettere con la città. Le indagini condotte avanzano l'ipotesi di una ricucitura urbana vista anche in funzione della collocazione del nuovo stadio AS Roma previsto a Tor di Valle in stretto contatto con il quartiere in questione.

Parole chiave

configurazione, pianificazione, abitare, analisi grafica, trasformazione.

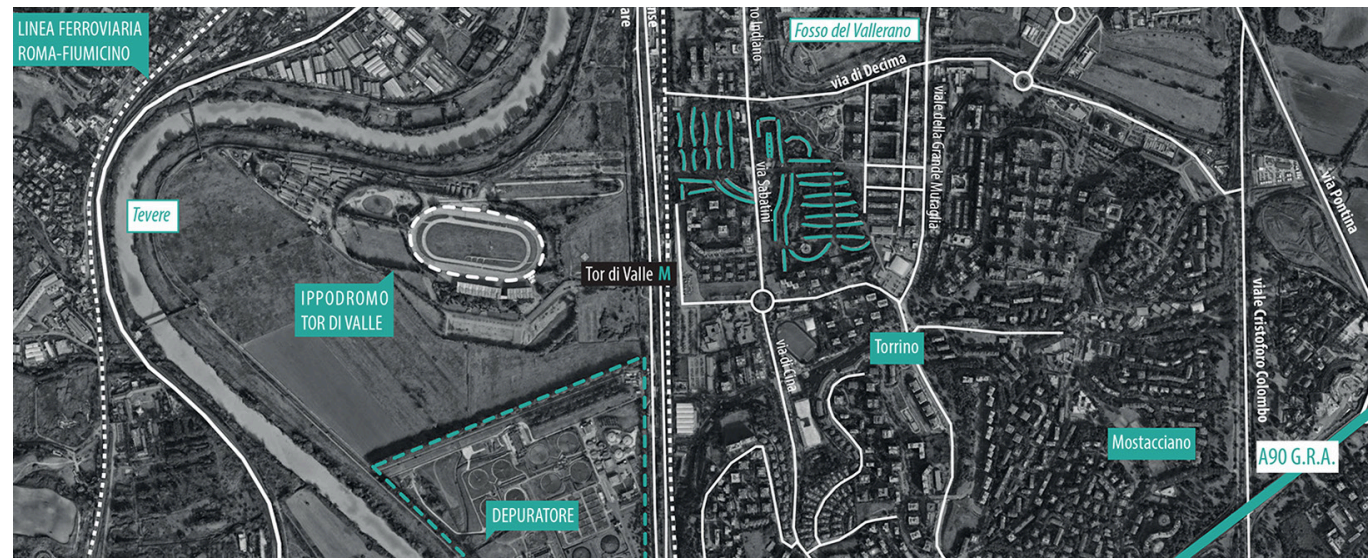




\section{Introduzione}

L'intento di rifondare scientificamente la disciplina architettonica spinge Luigi Moretti a definire un metodo di progettazione basato su regole obiettive, capaci di tradurre necessità e funzioni in forma [Moretti 1954, pp. 5-12].

La ricerca logico-matematica sui parametri che orientano il calcolo attraverso algoritmi capaci di strutturare la forma come frutto di un'equazione oggettiva richiedeva apporti multidisciplinari, a tale scopo l'architetto nel 1957 fonda l'Istituto Nazionale di Ricerca Matematica e Operativa per l'Urbanistica, IRMOU, di cui fanno parte esperti di diversi settori tra cui Bruno De Finetti, considerato tra i migliori matematici dell'epoca [Cuzzer, Bertuglia, Cristoforo 20 I0, pp. 43I-435].

L'ambizioso progetto tenta di stabilire i fondamenti della teoria parametrica cercando di interpretare le esigenze del vivere contemporaneo attraverso modelli astratti esposti alla XII Triennale di Milano del 1960. In questa occasione vengono mostrati i prototipi in gesso di campi per il calcio, il nuoto, il tennis e la sala cinematografica che esemplificavano i risultati raggiunti per garantire una buona visibilità a tutti gli spettatori da ogni punto dell'impianto. Durante l'esposizione le innovative forme potevano, inoltre, essere modificate in tempo reale attraverso l'ausilio di un elaboratore, uno dei primi computer monoutente, l'IBM 6I0, che permetteva al visitatore di cambiare, a titolo esemplificativo, alcuni parametri ottenendo la variazione della forma [Moretti 1971, pp. 30-53].

L'avvenimento come riferisce Moretti desta un certo clamore permettendo di divulgare i risultati deducibili dalle applicazioni condotte sulle strutture parametriche, a cui anche la critica guardava con interesse. Dopo gli stadi e le grandi strutture l'indagine si rivolge al tema dell'abitazione, al problema della distribuzione e funzionalità degli alloggi, dell'organizzazione degli ambienti, degli spazi in rapporto alle superfici finestrate, esaminate per definire le 'case parametriche'. Le immagini relative alla biennale fiorentina del 1965 intitolata La casa Abitata mostrano lo studio dell'architetto in cui compare il simulatore analogico, lo strumento che avrebbe dovuto interpretare le complesse espressioni matematiche, su cui elaborare i parametri, traducibili in modelli.

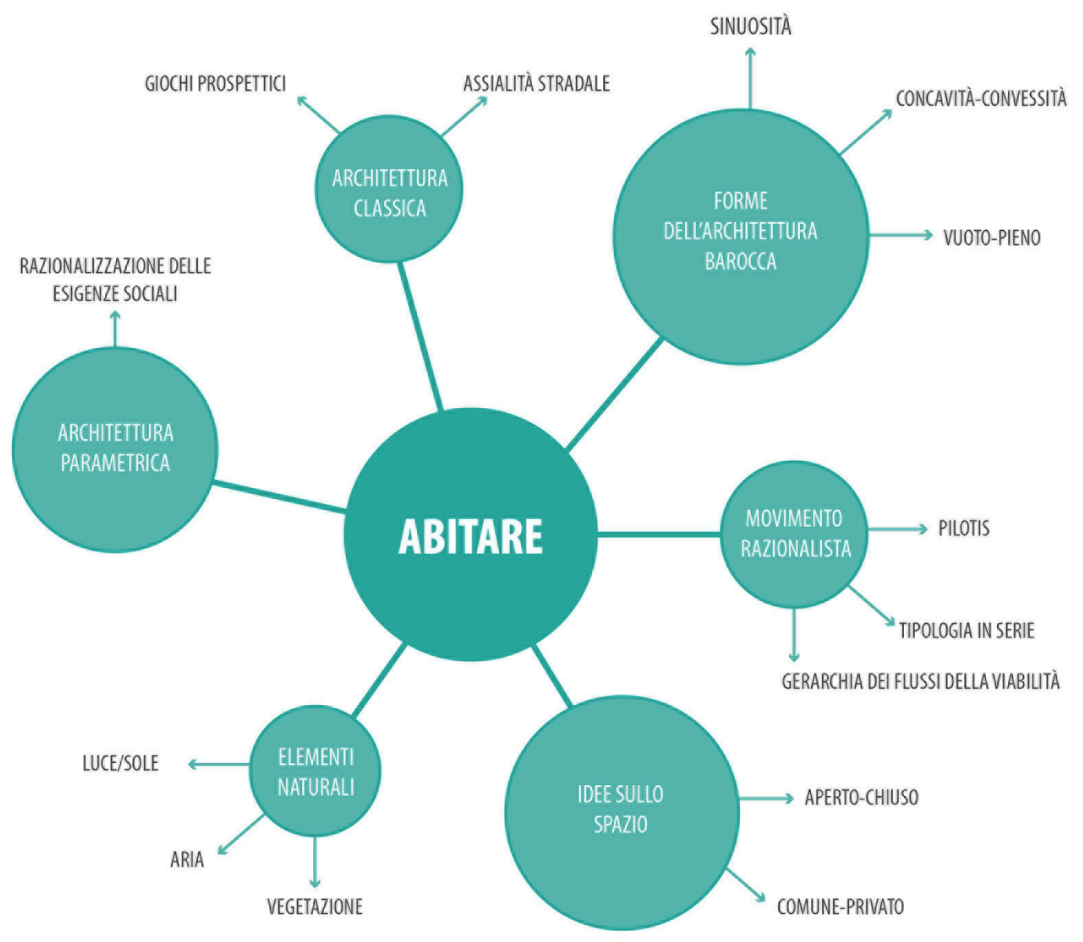


Fig. 2. Schizzi di Luigi Moretti per il quartiere Decima.
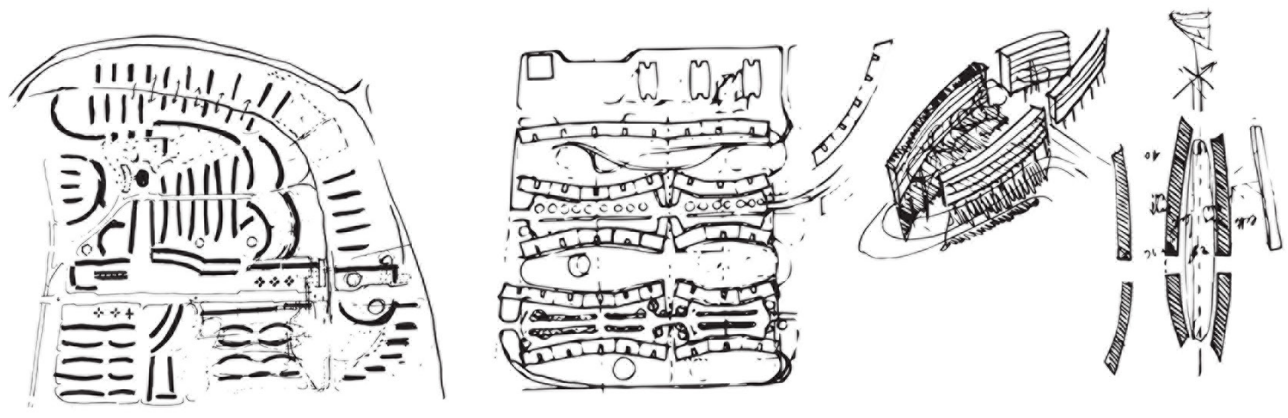

La mancanza di processori capaci di gestire una così enorme mole di dati non permise allora di portare a termine le interessanti proposte del gruppo presieduto da Moretti che, nonostante gli sforzi compiuti, non riesce a concretizzare ma solo ad avviare il sogno di una 'progettazione scientifica'.

I progressi ottenuti dall'evoluzione digitale hanno successivamente consentito elaborazioni complesse sostenendo lo sviluppo delle teorie parametriche, rese possibili da specifici programmi di modellazione. Software come Grasshopper permettono oggi di generare la forma attraverso una sequenza di algoritmi basati su un sistema di legami parametrici, da cui si determinano le differenziazioni della forma. II modello tridimensionale può essere in tal modo configurato e modificato in tempo reale tramite diagrammi [Tedeschi 2014, pp. 204-2I6].

Le anticipazioni di Moretti ribadiscono l'importanza del ruolo teorico, i concetti fondativi da cui sono scaturiti molti scritti, connessioni multidisciplinari, interlocuzioni scientifiche e artistiche che hanno condotto alla concretizzazione del lungimirante progetto operativo.

Le sperimentazioni sull'abitare, gli studi sui flussi di traffico applicati ai quartieri modello, progettati negli stessi anni, rendono pertanto utile una rilettura delle scelte adottate nel disegno di aree da urbanizzare.

I quartieri romani per l'INCIS, il Villaggio Olimpico e Decima, con il corrispettivo Watergate Complex a Washington, realizzati tra il 1960-1965 rappresentano la concretizzazione le scelte operative messe in atto per delineare gli spazi e le forme del vivere contemporaneo [Moretti 1962, pp. 109-122].

Lo spazio umano diventa un parametro su cui modellare le strutture abitative, la loro disposizione che trae spunto dalla lettura dell'antico, dalla sinuosità dell'architettura barocca impiegata non solo nella conformazione degli edifici, ma nel loro rapporto con gli spazi che li circondano. Un disegno che mette in relazione pieni e vuoti definiti nella logica della condivisione degli spazi, un esperimento sociale che considera il tema della residenza, dello spazio privato in connessione con quello pubblico.
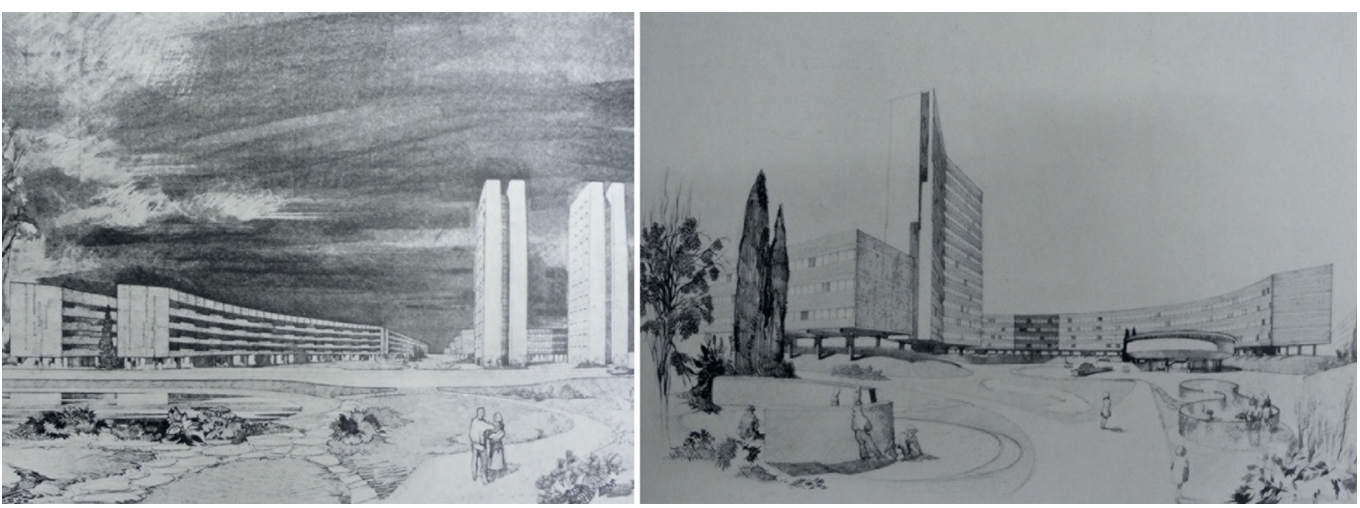


\section{I progetti per i quartieri romani}

Negli anni sessanta Moretti che fino ad allora aveva affrontato principalmente le tematiche dell'architettura, relativa a singoli edifici, inizia ad occuparsi dell'urbanistica, dei quartieri residenziali. Le esperienze romane coincidono con un momento significativo per la città che si apprestava a rinnovarsi con l'introduzione di un moderno Piano Regolatore che la prefigurava come una grande metropoli.

La capitale viene immaginata con uno sviluppo tangenziale che, partendo dal ramo nord dell'autostrada del Sole si sarebbe esteso lasciando fuori la città storica, fino alla pianura pontina una "struttura regolare quasi ippodamea" innestata tangenzialmente alla "struttura ricca di avventure classiche e barocche della Roma esistente" [Fabiani 1966, pp. 40-45].

La nuova Roma si sarebbe dunque dovuta sviluppare mantenendo la sua fisionomia, espandendosi per gemmazione, owero attraverso l'inserimento di insediamenti autosufficienti, residenziali e industriali, posti a una certa distanza dal nucleo storico.

Secondo Moretti il piano viene però studiato senza adeguate analisi sul tessuto urbano esistente, sullo stato di fatto esaminato in relazione alla distribuzione, alla struttura e alla composizione della popolazione, alla determinazione e localizzazione dei nuclei di lavoro compatibilmente con le risorse economiche e le condizioni residenziali del territorio.

In particolare l'architetto non condivide il tipo di sviluppo periferico proposto per Roma: svuotata dalla vita degli affari nel suo nucleo storico, la città sarebbe stata privata "del respiro possente della Roma antica" e del suo volto "ineffabile" per essere trasformata in una "smisurata città nuova"; lo spostamento ad est, inoltre, avrebbe contraddetto la figura "fondamentale e secolare" di Roma che "per sua natura allungata e porta il segno del Tevere". In tal senso la strutturazione di nuovi quartieri costituisce la chance per indirizzare la pianificazione, per applicare le concezioni teoriche dell'abitare.

\section{Villaggio Olimpico 1957-1960}

In occasione delle Olimpiadi del 1960 Moretti, insieme ad Adalberto Libera,Vincenzo Monaco, Amedeo Luccichenti e Vittorio Cafiero, viene coinvolto nella progettazione del Villaggio

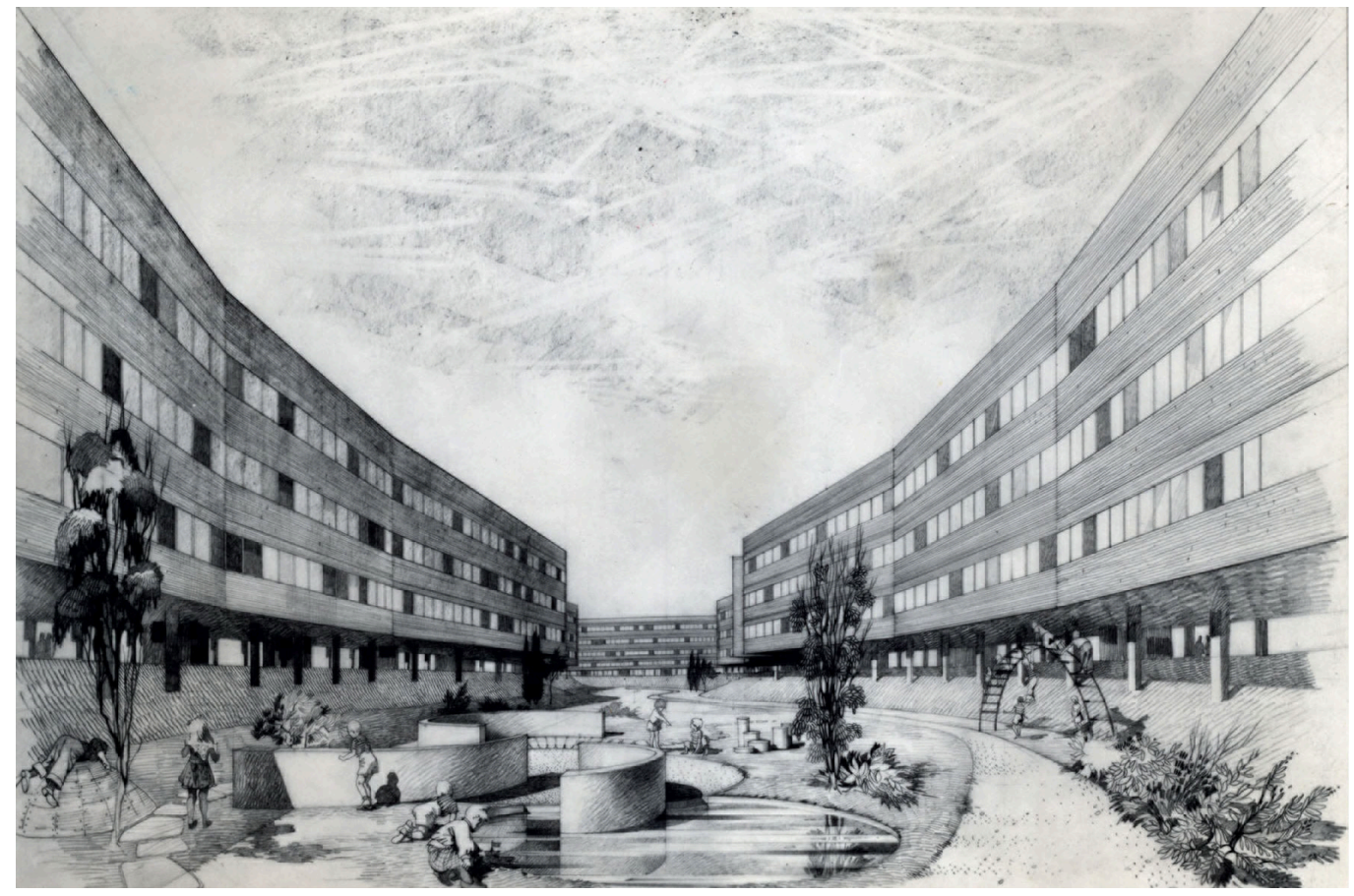


Fig. 5. Comparazioni analitiche tra lo stato di fatto e il progetto originario.
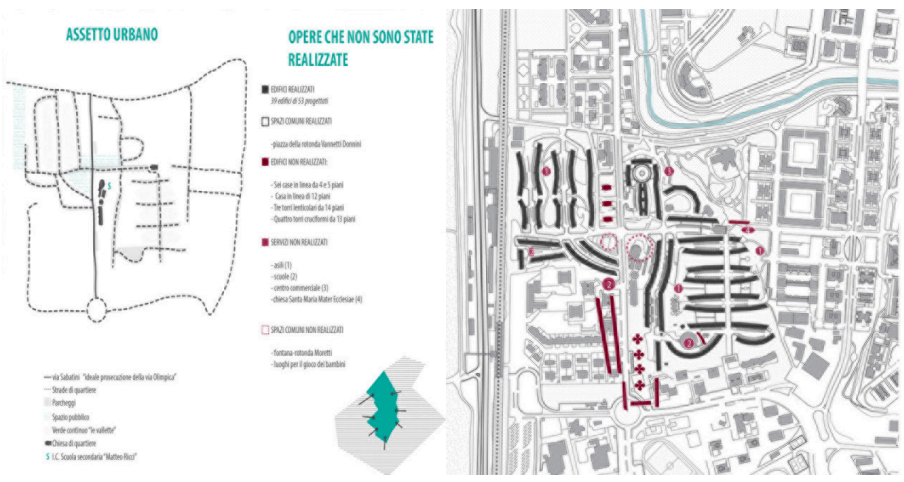

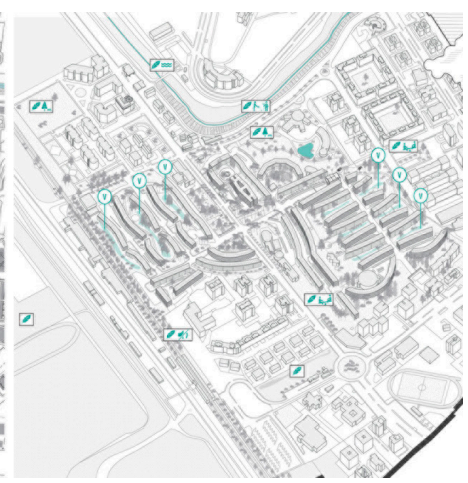

Olimpico realizzato per ospitare gli atleti durante il periodo dei giochi, ma che terminata la manifestazione sarebbe stato riconvertito in un quartiere residenziale. L'ipotesi di costruire attrezzature temporanee fu subito scartata in favore della costruzione di un villaggio con carattere stabile che avrebbe consentito, a Olimpiadi terminate, di alloggiare I 500 famiglie. La realizzazione fu perciò affidata a un istituto di interesse pubblico: I'INCIS, Istituto Nazionale per le Case agli Impiegati dello Stato che lo presenta come un quartiere modello.

L'esigenza era quella di organizzare alloggi per circa ottomila persone tra atleti, organizzatori, allenatori e rappresentanti della stampa, per dotare la capitale di tutti gli impianti e le attrezzature sportive utili allo svolgimento della competizione.

II progetto fu affidato ai più autorevoli architetti dell'epoca che pianificarono una superficie di circa 35 ettari con un complesso di palazzine, in linea e a croce, con altezza variabile da 2 a 5 piani, circondate da zone verdi e sollevate da terra su pilastri di cemento armato per lasciare libero e percorribile lo spazio alla quota urbana. Oltre alla costruzione delle opere edilizie risultò necessario definire un nuovo asse infrastrutturale a scorrimento veloce che collegasse la Cassia e la Flaminia con Viale Tiziano eViale Parioli al centro di Roma. II viadotto di Corso Francia, lungo circa un chilometro progettato da Pier Luigi e Antonio Nervi, per non compromettere la continuità del comprensorio fu sopraelevato salvaguardando l'organicità del quartiere svincolato dal traffico.

Il progetto suscita un grande interesse a livello internazionale, Le Corbusier lo visita, alla conclusione delle olimpiadi nel settembre del 1960, ritrovandovi le sue idee di urbanizzazione

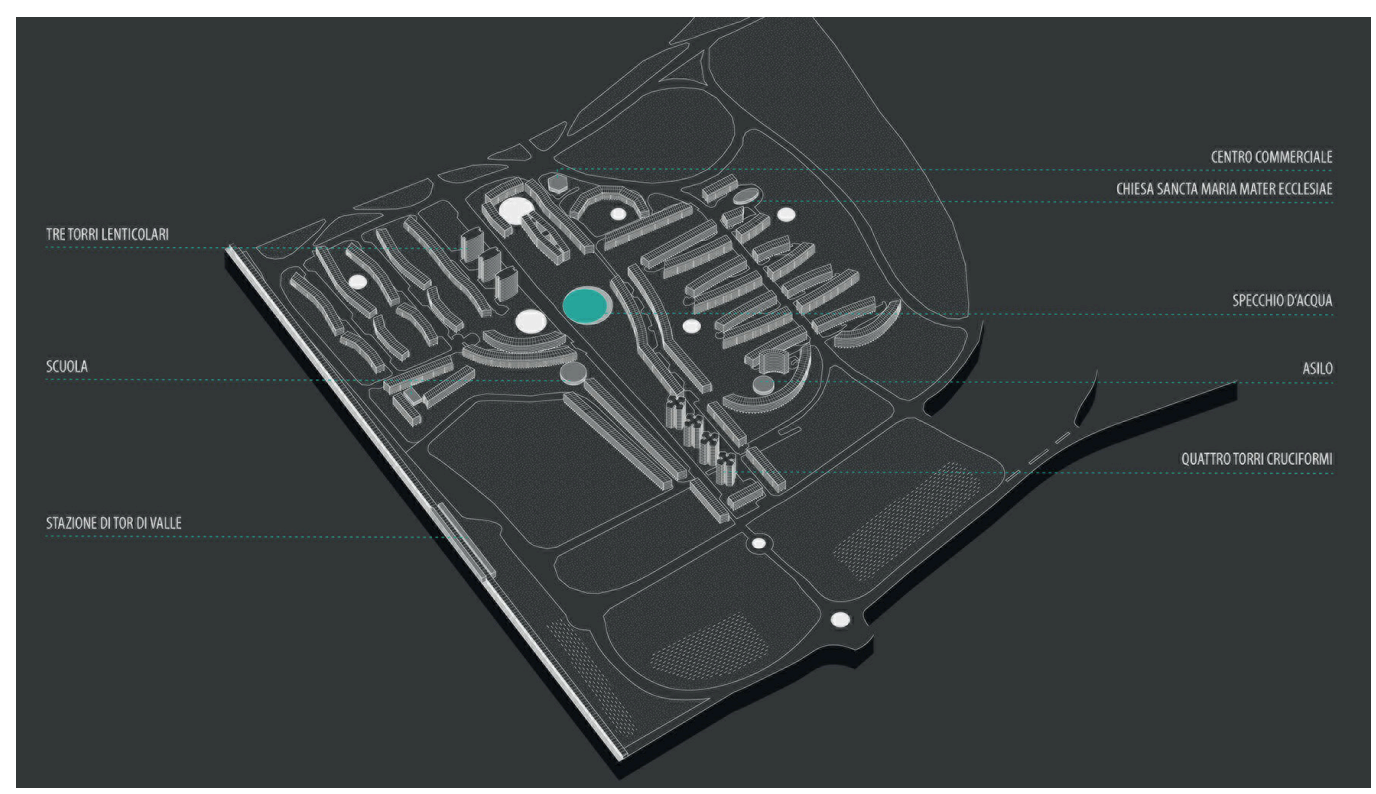



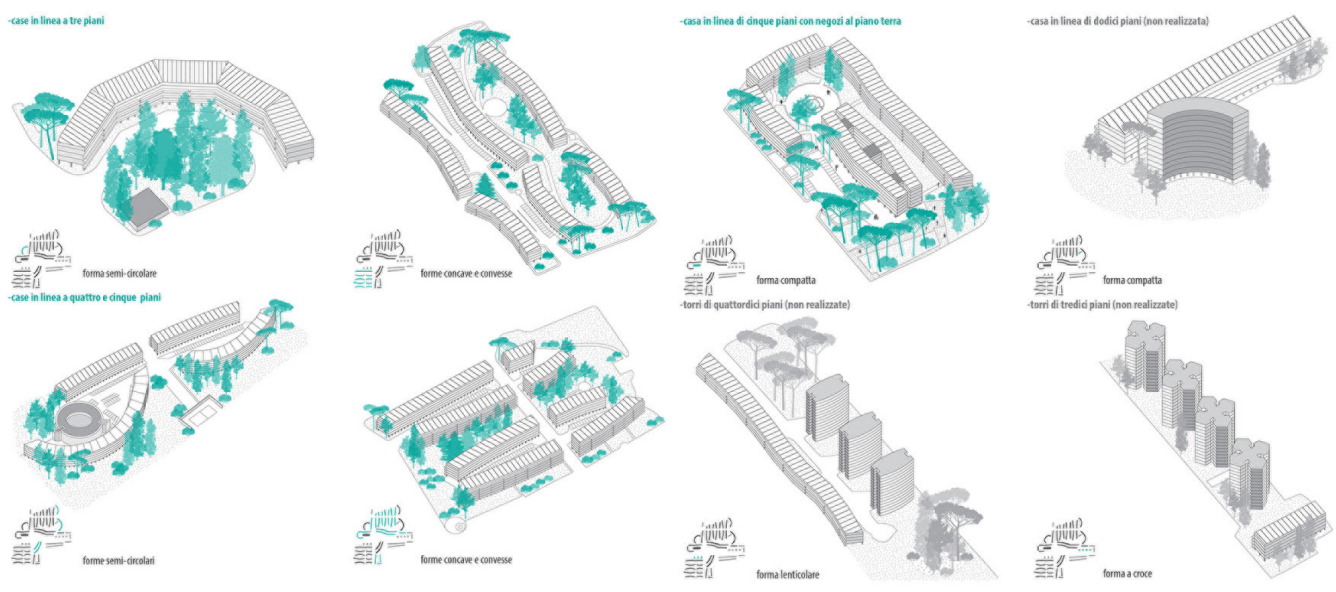

Fig. 8. Analisi tridimensio-

nale tipologia in linea a

cinque piani con distribu-

zione degli spazi abitativi.

Fig. 9. Prospetto di un brano del quartiere.
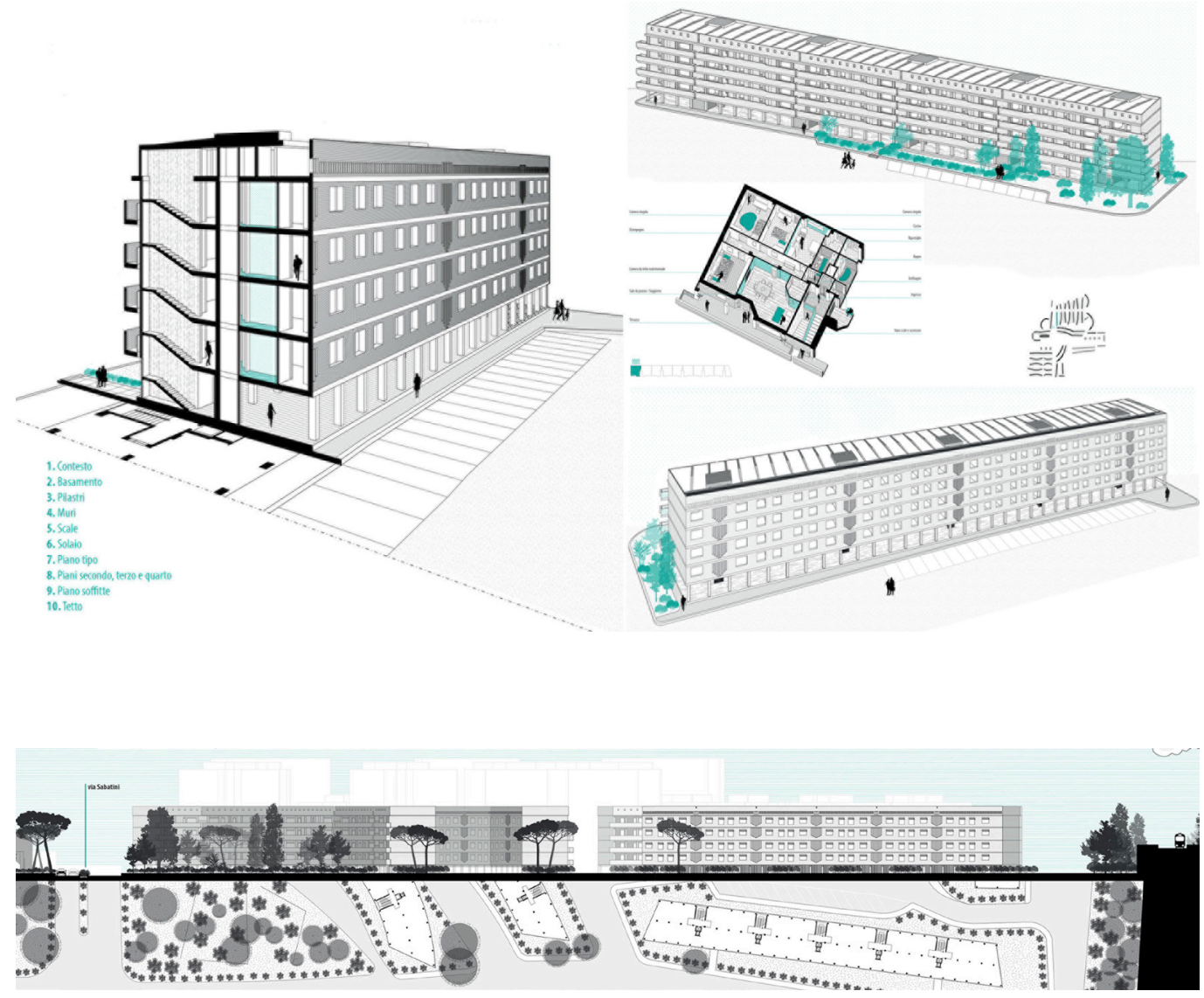
Fig. 10. Viste attuali del quartiere in cui si evidenziano le forme sinuose degli edifici che generano spazi concavi e convessi. della città; per la prima volta si realizza un quartiere autosufficiente dove l'unitarietà del complesso è garantita da un linguaggio coerente, definito da elementi comuni, uniformati dall'utilizzo dei pilotis dagli spazi impiegati in maniera funzionale [Talamona 20 I 0, pp. 313-327]. Gli apprezzamenti del maestro francese ebbero un grande risalto e verosimilmente incoraggiarono le soluzioni del piano urbanistico per il quartiere INCIS Decima, redatto in quegli anni dallo stesso Moretti con Libera, Cafiero e Ignazio Guidi, in cui si ripropone il sistema dei pilotis e degli impianti viari organizzati gerarchicamente per servire gli spazi comuni e il verde, intesi come sistema di relazione per gli abitanti.
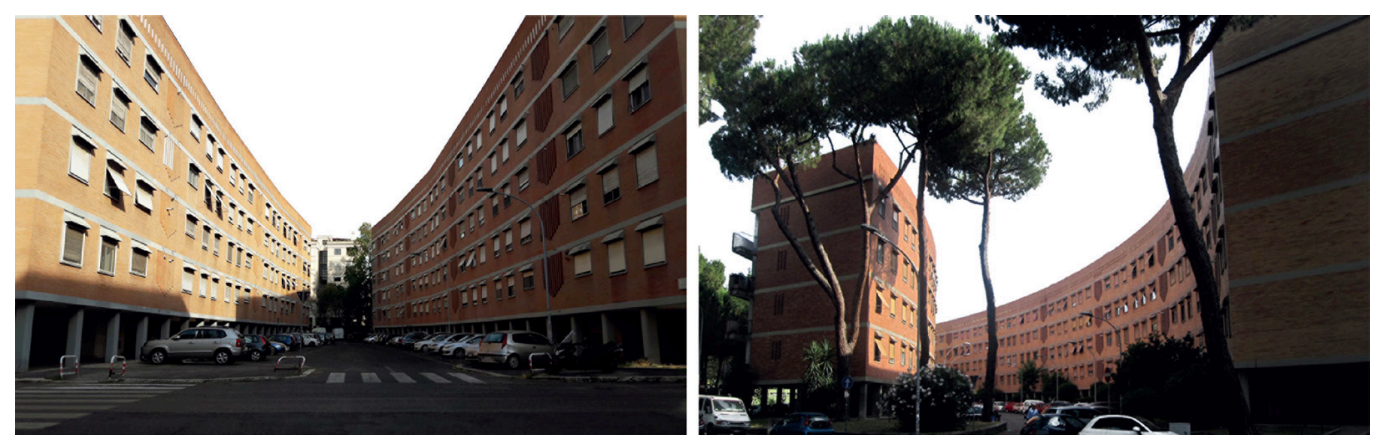

\section{Quartiere INCIS Decima. Le intenzioni progettuali}

Decima nasce in un periodo storico fortunato, nel pieno del boom economico e come anticipato sulla scia delle Olimpiadi del 1960 che avevano portato alla costruzione dell'omonimo Villaggio. Per entrambi i quartieri svolge un ruolo fondamentale l'ente che ha finanziato le opere, I'INCIS che si rivolge al ceto medio con la costruzione di alloggi ad uso degli impiegati dello Stato e delle loro famiglie, offrendo standard e comfort maggiori rispetto a quelle delle case popolari, promosse dallo IACP. La collocazione dei suddetti quartieri è in tal senso privilegiata in quanto, malgrado interessino aree periferiche, risultano collocati nelle vicinanze dei grandi centri dirigenziali, nella zona del Flaminio e dell'E.U.R. [Moretti 1962, pp. I09- | | 5].

In quegli anni si era puntato sull'espansione a sud della capitale, considerando lo sviluppo della zona E.U.R. e la volontà di spingersi verso il mare seguendo il corso del Tevere. In tal senso la variante al Piano Regolatore del 1962 predispone la costruzione di nuovi centri residenziali nella zona sud, in cui si colloca il quartiere di Decima, inserito sul tracciato della ferrovia metropolitana Roma-Ostia Lido.

Luigi Moretti assume il coordinamento generale del piano urbanistico e considera il quartiere un'occasione per sperimentare le sue teorie sull'abitare, pertanto lo immagina come un insieme abitativo in cui egli stesso avrebbe potuto vivere, immedesimandosi con le esigenze dell'utenza.

L'area viene completamente modellata per assecondare le esigenze dei fruitori a partire dalla viabilità impostata su tre livelli con quote differenziate, dall'asse inter-quartiere a scorrimento veloce dato dal prolungamento della Via Olimpica ( I $3 \mathrm{~m}$. slm), alla viabilità intra-quartiere ( I I m. slm), alle zone pedonali e relativi spazi per i bambini, per le scuole e gli asili (8 m. slm).

I diversi livelli risultavano collegati, ma indipendenti fra loro per garantire che le strade carrabili di quartiere potevano all'occorrenza passare sotto la grande arteria inter-quartiere, le vie pedonali a loro volta si inserivano sotto le carrozzabili creando passaggi in piena sicurezza senza attraversamenti veicolari.

Una viabilità organizzata per assecondare il moderno stile di vita degli abitanti, basata sulla quotidianità contemporanea in cui quasi tutte le famiglie possedevano almeno un'automo- 
bile, in cui c'era la necessità di avere parcheggi sufficienti, pensati con un assetto urbano che prevedesse una chiara separazione dei flussi.

Le dinamiche degli spazi sono state studiate per connettere e per creare coesione tra i residenti, Moretti ha ben chiara la differenza tra lo spazio del singolo e lo spazio della collettività. L'idea è quella di dar vita ad un quartiere che privilegi il concetto di vicinato, dotato di un ruolo sociale che si materializza attraverso precise scelte urbanistiche e architettoniche. L'esame delle tavole di progetto e gli 'schizzi' elaborati da Moretti permettono di comprende il valore innovativo dell'intervento proposto. La scelta delle tipologie, la loro disposizione in rapporto con il verde, concepito come un elemento continuo che attraverso lo 'svuotamento' del piano terra dei fabbricati, i portici con i pilotis, connette visivamente l'intero quartiere. Una fluidità visiva che scorre e si dilata nelle 'vallette' ricavate tra le forme avvolgenti dei fabbricati. II termine 'vallette' viene appositamente ideato dall'architetto per definire gli spazi verdi situati nelle concavità generate dai fabbricati, come elementi distintivi rispetto agli altri spazi verdi del quartiere.

Fig. I I.Viste attuali del quartiere in cui si evidenziano le visuali prospettiche generate dagli edifici, gli spazi verd e carrabili, l'attenzione per i materiali e per i dettagli architettonici.
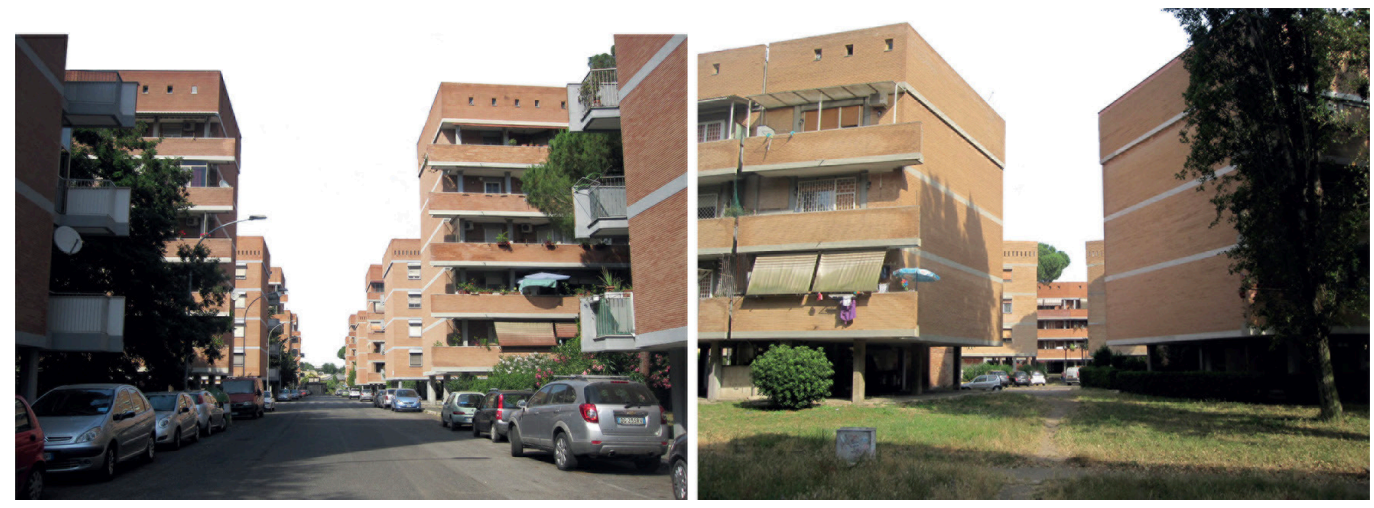

\section{Analisi stato di fatto: differenze, trasformazioni, criticità}

Esaminando lo stato di fatto sono state riscontrate una serie di differenze rispetto al progetto originario, alcune riguardano le opere non realizzate: 39 edifici residenziali rispetto ai 53 progettati che escludono le 6 case in linea da 4 e 5 piani, la casa in linea di 12 piani di forma semicircolare, le tre torri lenticolari da 14 piani e le 4 torri cruciformi da 13 piani.

Il quartiere è stato inoltre privato di spazi comuni come la fontana rotonda, di luoghi pensati per il gioco dei bambini e dei servizi: gli asili, le scuole, il centro commerciale e la Chiesa. Per la mancata realizzazione della chiesa, di cui rimane una vista prospettica dell'interno e alcuni schizzi, è importante considerare le correlazioni con le riflessioni teoriche, proposte dall'autore negli stessi anni, sugli spazi sacri. Nel 1962 in una conferenza intitolata Spazi luce nell'architettura religiosa, Moretti propone uno straordinario excursus sul ruolo della luce nell'architettura sacra, che va dal Pantheon alle chiese settecentesche. Lo studio delle forme elaborate per Sancta Maria Mater Ecclesiae a Decima trovano chiari riscontri con la coerenza metodologica e la ricerca scientifica sul tema che parte dall'antico per arrivare alla definizione di uno spazio avvolgente come richiesto dalla riforma conciliare. La mancata realizzazione non permette un riscontro materiale, restano gli studi condotti sull'argomento e la necessità, indicata nel progetto e sentita dagli abitanti, della presenza di un luogo sacro dove la comunità potesse riunirsi che ha successivamente portato alla realizzazione di una piccola chiesetta prefabbricata.

Tornando alle difformità, analizzate con ipotesi ricostruttive condotte e rappresentate attraverso modelli digitali confrontati con la realtà attuale, sono state evidenziate le trasformazioni in particolare quelle viarie che hanno condizionato i sistemi dello spazio pubblico e delle aree verdi, pregiudicando i livelli di viabilità che, come descritto, costituivano un punto nodale del progetto. Nelle analisi grafiche è possibile osservare il rapporto tra la viabilità 
originaria e quella attuale, l'asse centrale appare oggi congestionato dal traffico che ha compromesso la viabilità pedonale interna e l'originaria fruizione degli spazi verdi.

L'abolizione delle 7 tipologie a torre che svettavano sulla ideale prosecuzione della via Olimpica mettendo in luce il quartiere, ha ridotto il legame visivo e concettuale con il Foro Olimpico e l'EUR.

Altre criticità sono da attribuire alle trasformazioni prodotte da successive espansioni che, con il loro sviluppo intensivo, hanno inglobato il tessuto circostante. II limitrofo quartiere Torrino si è esteso nell'area di Decima prendendone alcune porzioni, come nel caso della scuola secondaria 'Matteo Ricci' costruita per soddisfare gli standard urbanistici del nuovo insediamento, al posto del previsto e non realizzato specchio d'acqua.

La scuola è un caso emblematico, poiché la qualità architettonica dell'edificio è decisamente discutibile e non si relaziona con le concezioni abitative del quartiere.

\section{Conclusioni}

Nel corso degli anni le stratificazioni sono state molteplici, il piano di zona ha occupato i vuoti urbani lasciati dalle mancate realizzazioni del progetto per Decima, purtroppo indebolendo la matrice del quartiere stesso che è diventato un luogo di passaggio dove pochi riconoscono il valore architettonico. Le indagini condotte sul progetto originario hanno rilevato le trasformazioni e le criticità riferendole alle intenzioni che Moretti aveva per quest'area, un modello abitativo che è andato via via ridimensionandosi, ma nell'impianto preserva le sue connotazioni.

I risultati raggiunti con le analisi grafiche, le connessioni tra le concezioni teoriche e le scelte operative effettuate dal progettista, condotte attraverso il disegno e le riconfigurazioni digitali [ $\mid$ ], indicano la direzione per una possibile riqualificazione, dettata dagli stessi presupposti progettuali. In conclusione, l'analisi effettuata indirizza la riorganizzazione dei rapporti tra gli spazi pubblici e l'abitato, tra il quartiere e il suo intorno prendendo spunto dalle nuove connessioni come quella della prossima realizzazione dello stadio a Tor di Valle che costituisce un'occasione per la rinascita di Decima che, se non sfruttata, porterà ad un ulteriore compressione sul piano urbanistico e sociale. Le connessioni spazio_forma_struttura ricercate da Moretti possono ancora definire legami, generare ricuciture tra le trascurate periferie, nel caso specifico d'autore, e le nuove polarità urbane.
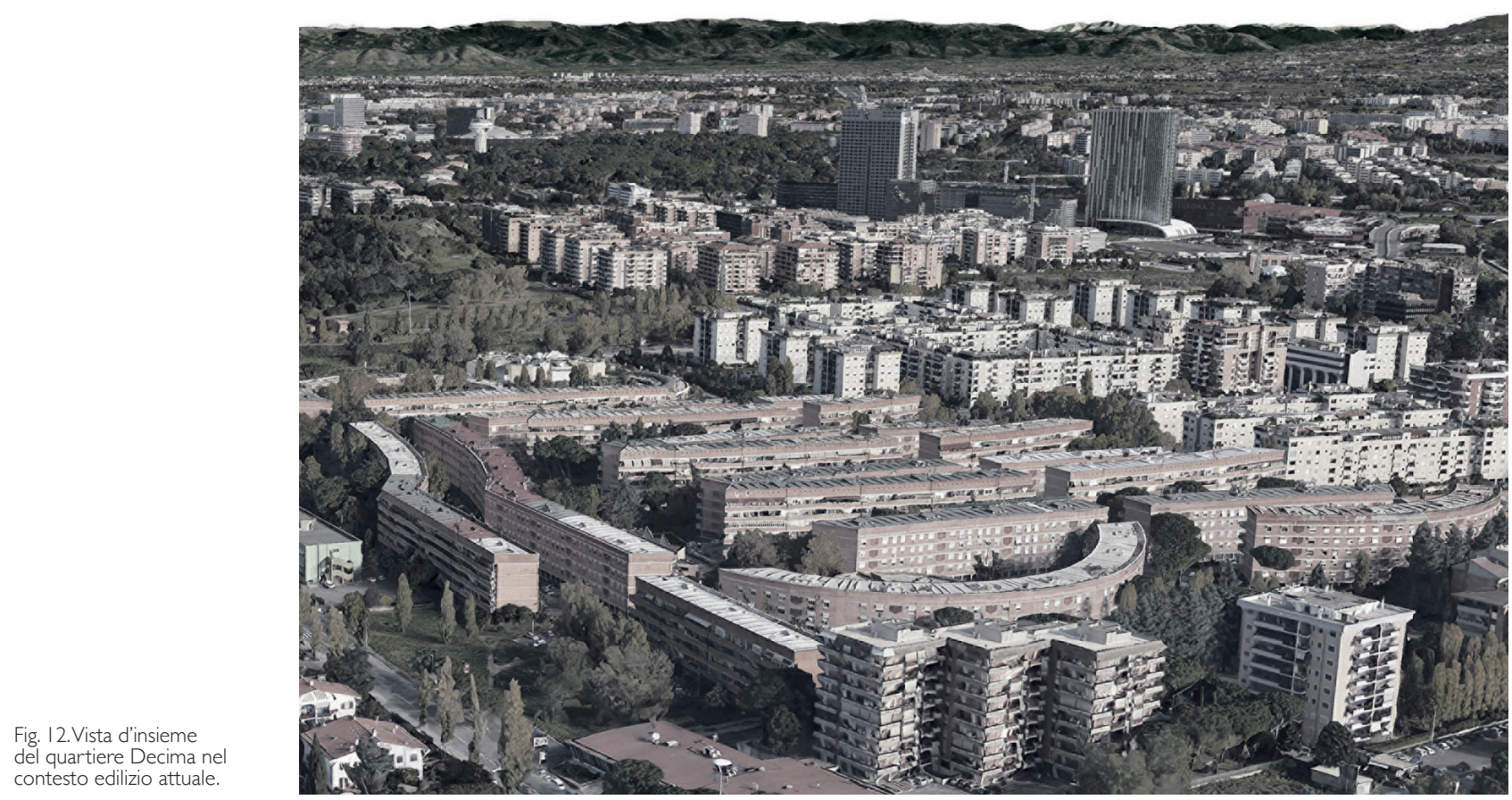


\section{Note}

[I] La ricerca è stata svolta con la collaborazione dell'architetto Celeste D'Ercoli.

\section{Riferimenti bibliografici}

Bozzoni Corrado, Fonti Daniela, Muntoni Alessandra (2012). Luigi Moretti. Architetto del Novecento. Roma: Gangemi Editore.

Bucci Federico, Muzzalani Marco (2000). Luigi Moretti. Opere e scritti. Milano: Electa.

Casciato Maristella,Viati Navone Annalisa (20 I0). Luigi Moretti architetto. Dal razionalismo allinformale. Guida alla Mostra MAXXI 30 maggio-28 novembre 2010. Milano: Electa.

Cuzzer Anna, Cordella Giovanni, Bertuglia Cristoforo (2010). Testimonianza. Ricordi dell'IRMOU. In Reichlin Bruno, Tedeschi Letizia (a cura di). Luigi Moretti, Razionalismo e trasgressività tra barocco e Informale. Milano: Electa, pp. 43I-35.

Fabiani Roberto ( 1966). Decima: quartiere sereno. In Capitolium, n. I, gennaio, pp. 40-45.

Finelli Luciana (2005). Luigi Moretti. La promessa e il debito. Architetture 1926- 1973. Roma: Officina edizioni.

Moretti Luigi (1954). Structure comme forme, in Spazio, n. 6, pp. 5- I2.

Moretti Luigi (1962). Nuovo quartiere Incis, nella zona EUR. in La Casa, 1962, n. n7, pp. I09- 122.

Moretti Luigi ( 197I). Ricerca matematica in Architettura e Urbanistica. In Moebius, n. I, pp. 30-53.

Rostagni Cecilia (2008). Luigi Moretti 1907-1973. Milano: Electa.

Reichlin Bruno, Tedeschi Letizia (20 I0). Luigi Moretti. Razionalismo e trasgressività tra barocco e Informale. Milano: Electa.

Rossi Piero Ostilio (2012). Guida all'architettura moderna 1909-2011. Roma-Bari: Laterza.

Spinelli Luigi (2012). Gli spazi in sequenza di Luigi Moretti. Siracusa: Lettera Ventidue.

Santuccio Salvatore (1986). Luigi Moretti. Bologna: Zanichelli.

Talamona Marida (20I0). II Villaggio olimpico. In Reichlin Bruno, Tedeschi Letizia (a cura di). Luigi Moretti. Razionalismo e trasgressività tra barocco e informale. Milano: Electa, pp. 313-327.

Tedeschi Arturo (20I4). AAD Algorithms-Aided Design. Parametric strategies using grasshopper. Brienza: Le Penseur.

\section{Autore}

Caterina Palestini, Università degli Studi dell'Adriatico "G. d'Annunzio" Chieti- Pescara, palestini@unich.it

Per citare questo capitolo: Palestini Caterina (2020). Connessioni spazio_forma_struttura. : Le teorie dell'abitare di Luigi Moretti, analisi e riconfigurazioni del quartiere Decima a Roma/Connections space shape structure. Luigi Moretti's theories of living, analysis and reconfigurations of the Decima District in Rome. In Arena A., Arena M., Brandolino R.G., Colistra D., Ginex G., Mediati D., Nucifora S., Raffa P. (a cura di). Connettere Un disegno per annodare e tessere. Atti del $42^{\circ}$ Convegno Internazionale dei Docenti delle Discipline della Rappresentazione/Connecting. Drawing for weaving relationships. Proceedings of the 42th International Conference of Representation Disciplines Teachers. Milano: FrancoAngeli, pp. 1276 - I 295. 


\title{
Connections Space_Shape_Structure. Luigi Moretti's Theories of Living, Analysis and Reconfigurations of the Decima District in Rome
}

\author{
Caterina Palestini
}

Abstract

The study moves within the context of the ideological connections theorized by Luigi Moretti in the artistic, architectural and urban planning fields. The ability to weave cultural comparisons with art, the correlations between structures and shape, the experiences conducted in the sixties by the ingenious architect constitute the foundation on which the operational investigations that trigger links between the design and the theoretical speculations from which the modern lexicon of living is derived. The contemporaneity of experimentation on parametric design, on the configuration of shape as a set of relationships, has oriented research on the themes proposed by the conference. The contribution retracing the Moretti assumptions falls on a concrete case: the INCIS Decima district in Rome, examining it through graphic analysis and digital reconfigurations. The investigation methodology highlights the transformations undergone with respect to the original project which proposed it as a functional and self-sufficient model in line with the new physical dimension of the modern city, in which the variety of urban spaces, the continuous green, and the streets took on a decisive role in relation to the built environment. Analyzing the current situation, the critical points, the unrealized elements, the additions and the stratifications that over time distorted the initial concepts have been indicated. The goal is to recover the essence of the project, of the place, that despite the transformations preserves a strong identity, to be re-connected with the city. The investigations carried out put forward the hypothesis of an urban re-stitching also seen as a function of the location of the new AS Roma stadium planned in Tor di Valle in close contact with the neighborhood in question.

Keywords

configuration, planning, living, graphic analysis, transformation.

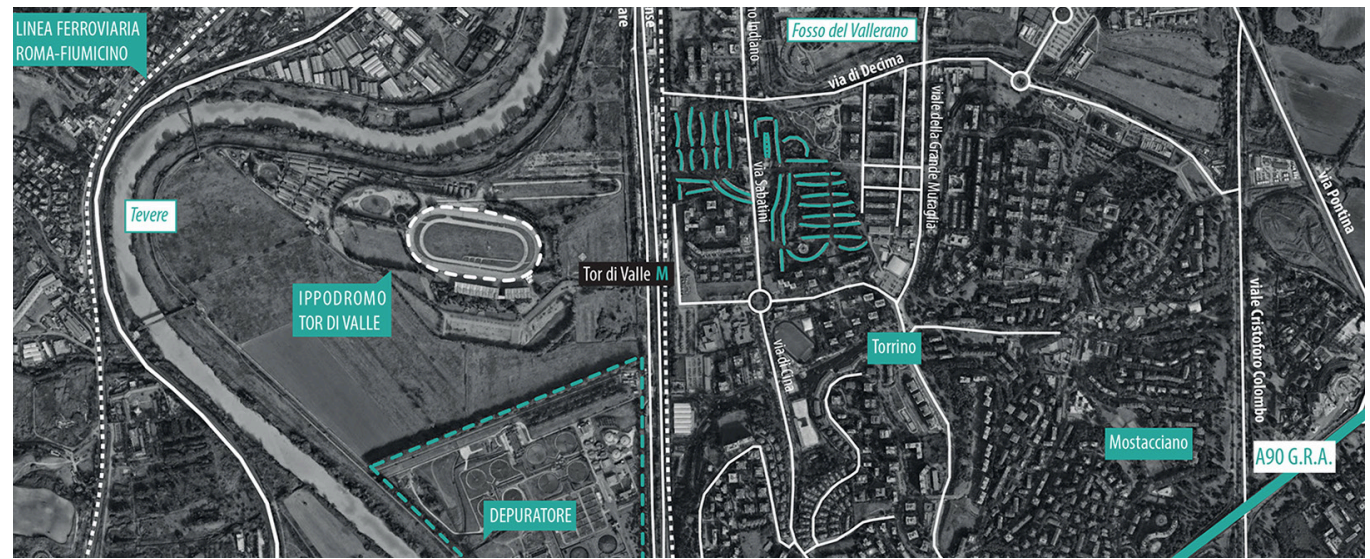




\section{Introduction}

The intention to scientifically re-establish the architectural discipline pushes Luigi Moretti to define a design method based on objective rules, capable of translating needs and functions into shape [Moretti 1954, pp. 5-12].

The logical-mathematical research on the parameters that guide the calculation through algorithms capable of structuring the shape as the result of an objective equation required multidisciplinary contributions, for this purpose in 1957 the architect founded the national institute of mathematical and operational research for the urban planning IRMOU, which includes experts from various sectors including Bruno De Finetti, considered among the best mathematicians of the time [Cuzzer, Bertuglia, Cristoforo 20 I0, pp. 43I-435].

The ambitious project attempts to establish the foundations of parametric theory by trying to interpret the needs of contemporary living through abstract models exhibited at the XII Triennale in Milan in 1960. On this occasion, the plaster prototypes of fields for soccer, swimming, tennis and the cinema are shown, which exemplified the results achieved to ensure good visibility to all spectators from every point of the system. During the exhibition, the innovative shapes could also be modified in real time through the aid of a computer, one of the first IBM 610 hand-held computers that allowed the visitor to change, by way of example, some parameters, obtaining the variation of the shape [Moretti 197I, pp. 30-53]. The event, as Moretti reports, arouses a certain fuss, allowing the results that can be deduced from the applications conducted on parametric structures to be disseminated, to which even critics looked with interest. After the stadiums and large structures, the investigation turns to the theme of housing, the problem of the distribution and functionality of housing, the organization of environments, and spaces in relation to surfaces with windows, examined to define "parametric houses". The images relating to the Florentine bienniale of I 965 entitled La Casa Abitata show the architect's study in which the analog simulator appears, the instrument that should have interpreted the complex mathematical expressions, on which to elaborate the parameters, which can be translated into models.

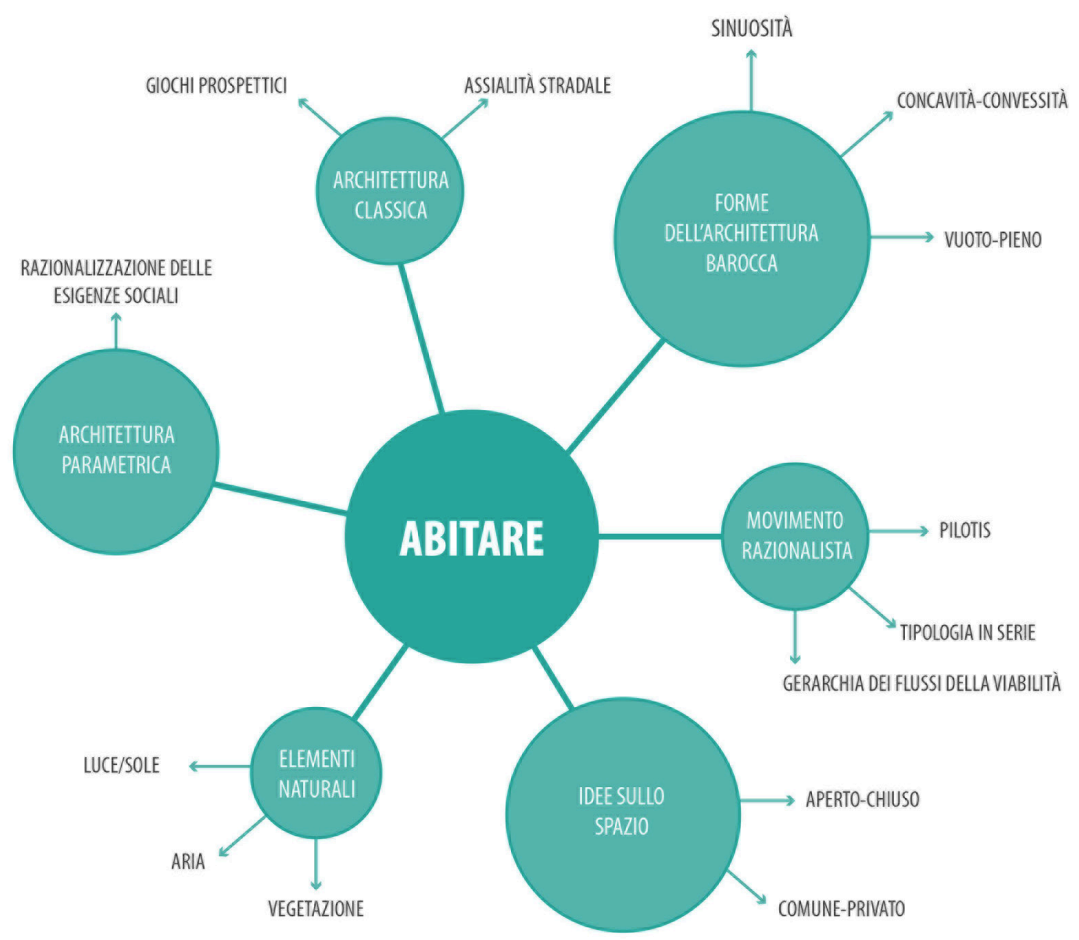


Fig. 2. Sketches by L. Moretti for the Decima district.
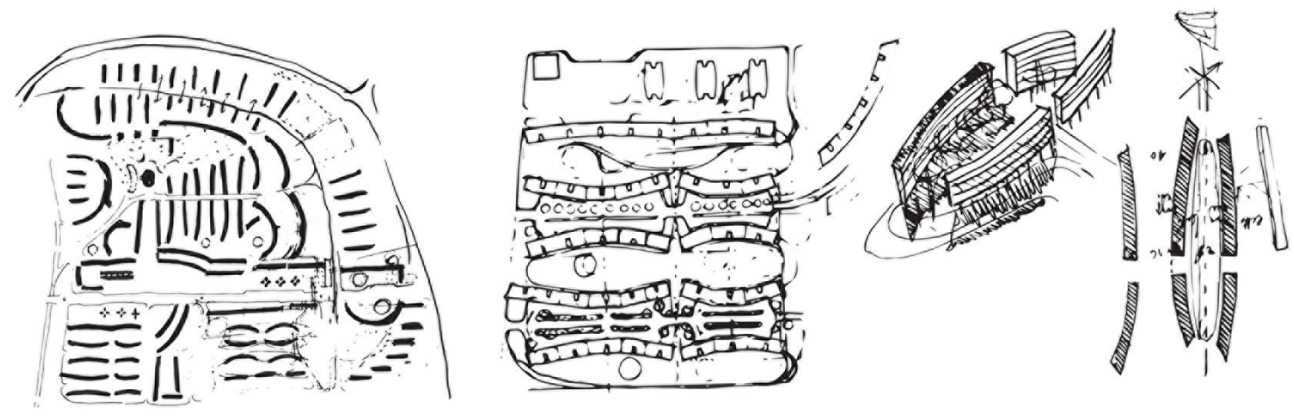

The lack of processors capable of managing such a huge amount of data did not allow the interesting proposals of the group chaired by Moretti to be completed which, despite the efforts made, fails to materialize but only to start the dream of a 'scientific design'. The progress obtained by digital evolution subsequently allowed complex elaborations supporting the development of parametric theories, made possible by specific modeling programs. Software such as Grasshopper now allows to generate the shape through a sequence of algorithms based on a system of parametric links, from which the differentiations of the shape are determined. The three-dimensional model can thus be configured and modified in real time through diagrams [Tedeschi 20I4, pp. 204-2I6].

Moretti's previews reiterate the importance of the theoretical role, the foundational concepts from which many writings, multidisciplinary concessions, scientific and artistic interlocutions that led to the realization of the forward-looking operational project.

The experimentation of living, the studies on traffic flows applied to the model neighborhoods, designed in the same years, therefore make it useful to re-read the choices made in the design of areas to be urbanized.

The Roman quarters for the INCIS, the Olympic Village and Decima, with the corresponding Watergate Complex in Washington, built between 1960-65 represent the concretization of the operational choices put in place to outline the spaces and shapes of contemporary living [Moretti 1962, pp. I09-I22].

Human space becomes a parameter on which to model housing structures, their arrangement that draws inspiration from the reading of the ancient, from the sinuosity of Baroque architecture used not only in the confirmation of buildings, but in their relationship with the spaces that surround them. A design that relates full and empty spaces defined in the logic of sharing spaces, a social experiment that considers the theme of residence, of private space in connection with the public one.
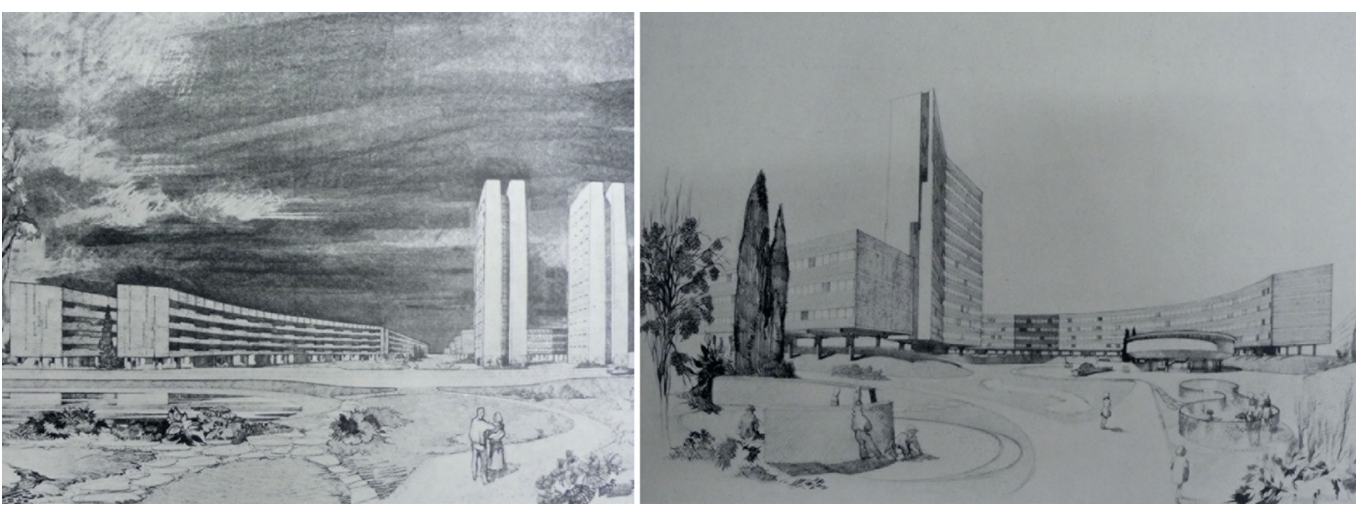


\section{The projects for the Roman districts}

In the 1960's Moretti, who until then had mainly dealt with the issues of architecture, relating to individual buildings began to deal with urban planning and residential districts. The Roman experiences coincide with a significant moment for the city that is preparing to renew itself with the introduction of a modern Town Plan which foreshadowed it as a large metropolis. The capital is imagined with a tangent development that, starting from the northern branch of the Autostrada del Sole would have extended leaving the historical city outside, to the pontine plain a "almost hippodamean regular structure" grafted tangentially to the "structure full of classic and baroque adventures of existing Rome" [Fabiani 1966, pp. 40-45].

The new Rome should therefore have developed keeping its physiognomy, but expanding by budding, or through the insertion of self-sufficient residential and industrial settlements, placed at a certain distance from the heart of the city.

According to Moretti, however, the plan is studied without adequate analysis on the existing urban fabric, on the factual situation examined in relation to the distribution, structure and composition of the population, the determination and location of the work units compatibly with economic resources and residential conditions of the territory.

In particular, the architect does not share the type of peripheral development proposed for Rome: emptied from business life in its historical core, the city would have been deprived of the "mighty breath of ancient Rome" and its "ineffable" face to be transformed in a "huge new city"; the move to the east, moreover, would have contracted the "fundamental and secular" figure of Rome, which "by its nature stretched and bears the sign of the Tevere". In this sense, the structuring of new neighborhoods is the chance to direct planning, to apply the theoretical concepts of living.

\section{Olympic Village 1957-1960}

On the occasion of the 1960 Olympics, Moretti, together with Adalberto Libera, Vincenzo Monaco, Amadeo Luccichenti andVittorio Cafiero, was involved in the design of the Olympic Village designed to host athletes during the games period, but which, once the event was

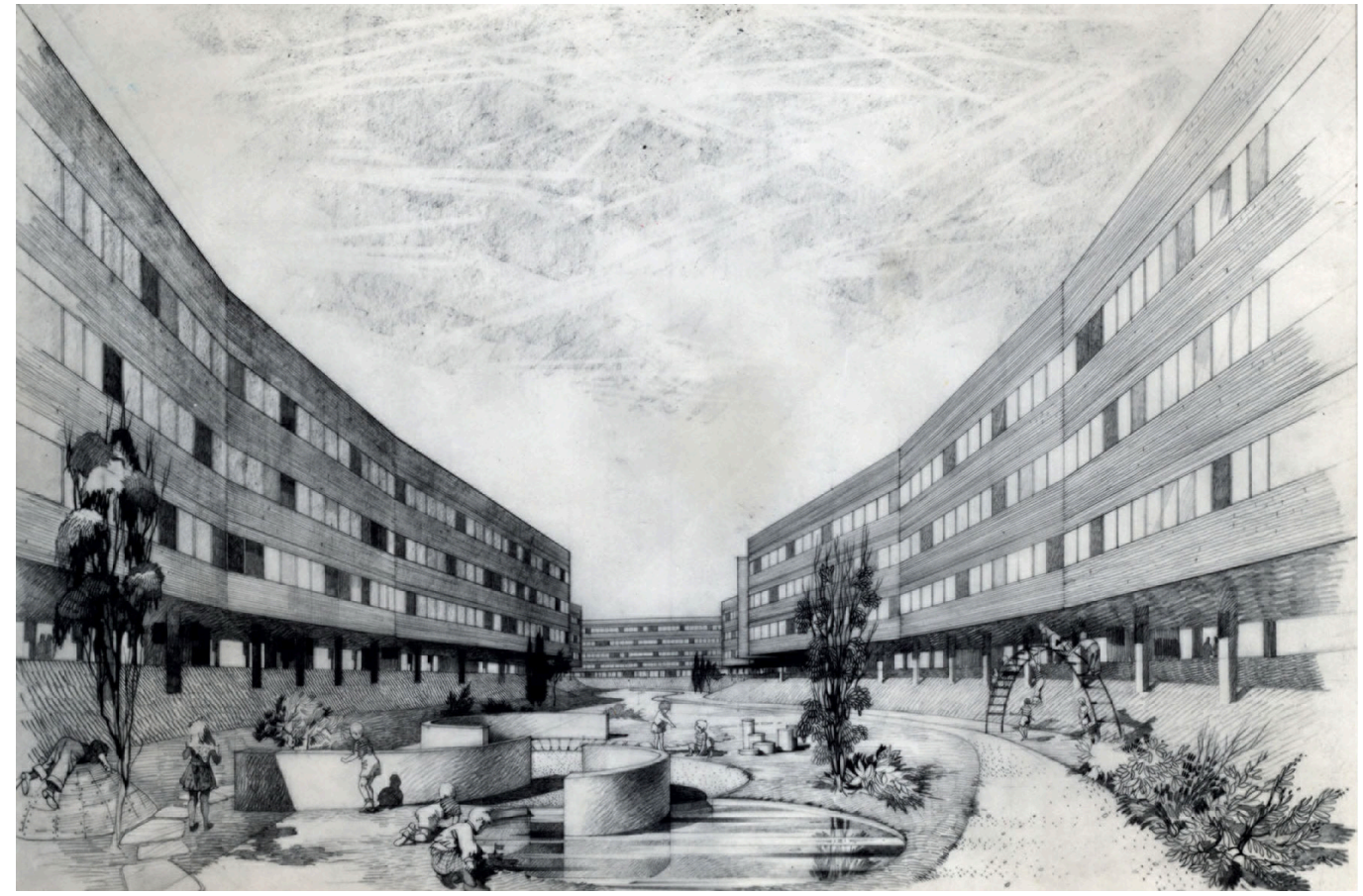


Fig. 5. Analytical comparisons between the state of affairs and the original project.
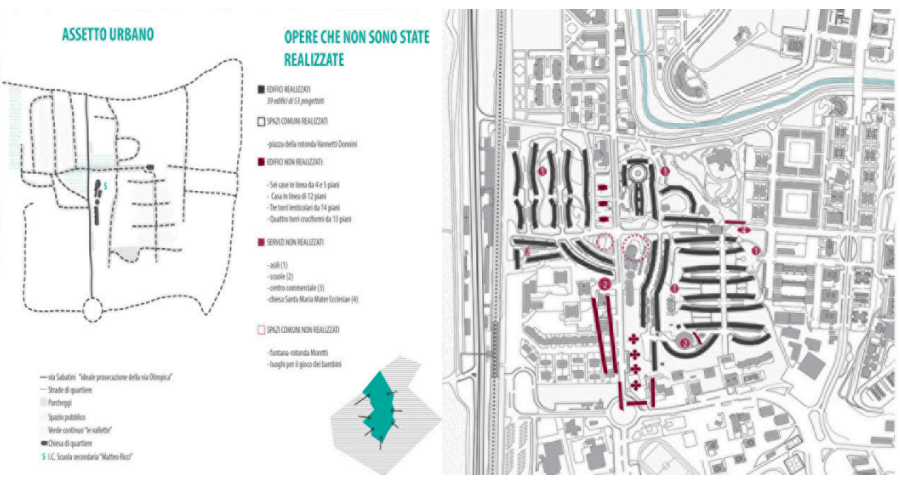

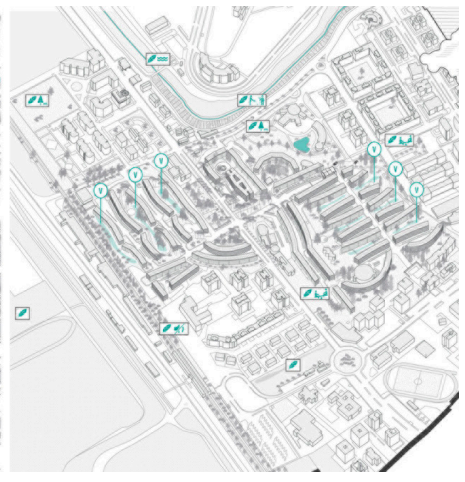

over, would have been converted into a residential district. The idea of building temporary equipment was immediately discarded in favor of the construction of a village with a stable character which would allow 1.500 families to stay at the end of the Olympics. The construction was therefore entrusted to an institution of public interest: the INCIS. The National Institute for Employee Homes of the State, which presents it as a model neighborhood. The need was to organize accommodation for about eight thousand people including athletes, organizers, coaches and representatives of the press, to equip the capital with all the facilities and sports equipment useful for carrying out the competition.

The project was entrusted to the most authoritative architects of the time who planned an area of about 35 hectares with a complex of buildings, in line and cross, with a height ranging from 2 to 5 floors, surrounded by green areas and raised from the ground on pillars of reinforced concrete to leave space at urban level free and passable. In addition to the construction of the building works, it was necessary to define a new fast-flowing infrastructure axis connecting the Cassia and Flaminia with Viale Tiziano and Viale Parioli in the center of Rome. The Corso Francia viaduct, about a kilometer long designed by Pier Luigi and Antonio Nervi, in order not to compromise the continuity of the area was raised, safeguarding the organic nature of the district free from traffic.

The project arouses great interest internationally. Le Corbusier visits him, at the end of the Olympics in September 1960, finding his ideas of urbanization of the city; for the first time, a self-sufficient neighborhood is created where the unity of the complex is guaranteed by a

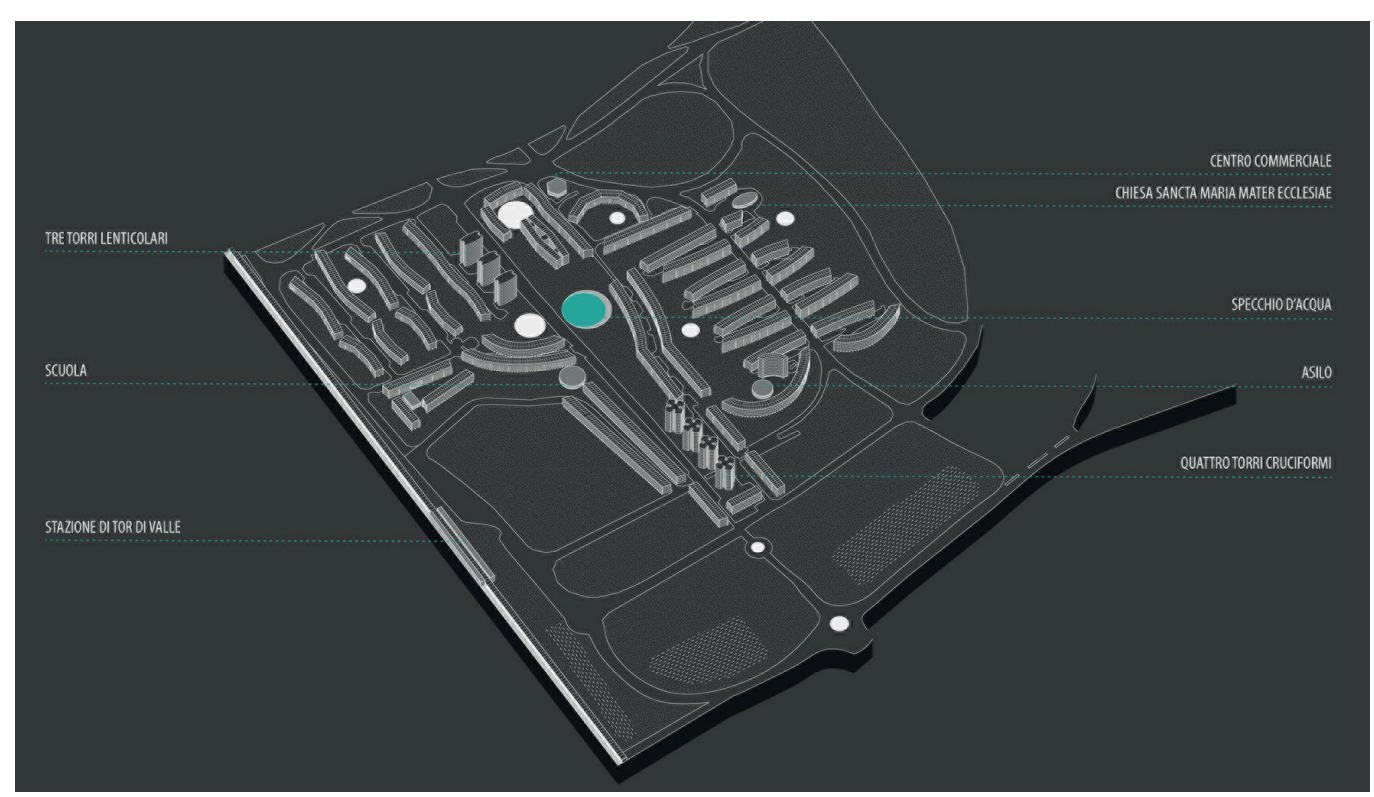


Fig. 7.Three-dimensional econstruction of the
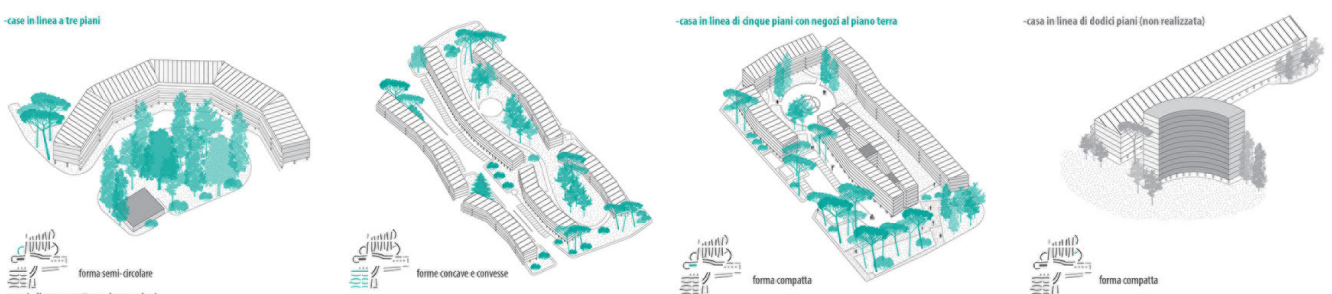

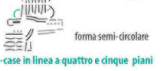

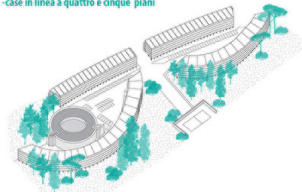

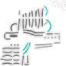
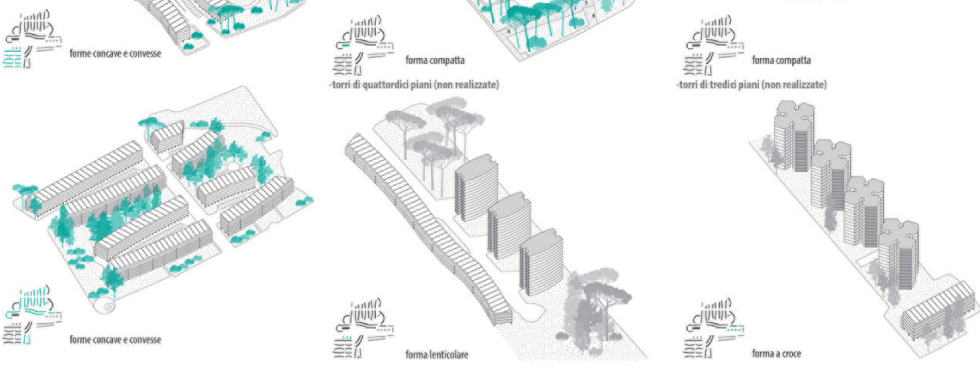

Fig. 8. Three-dimensional typology analysis in line with five floors with
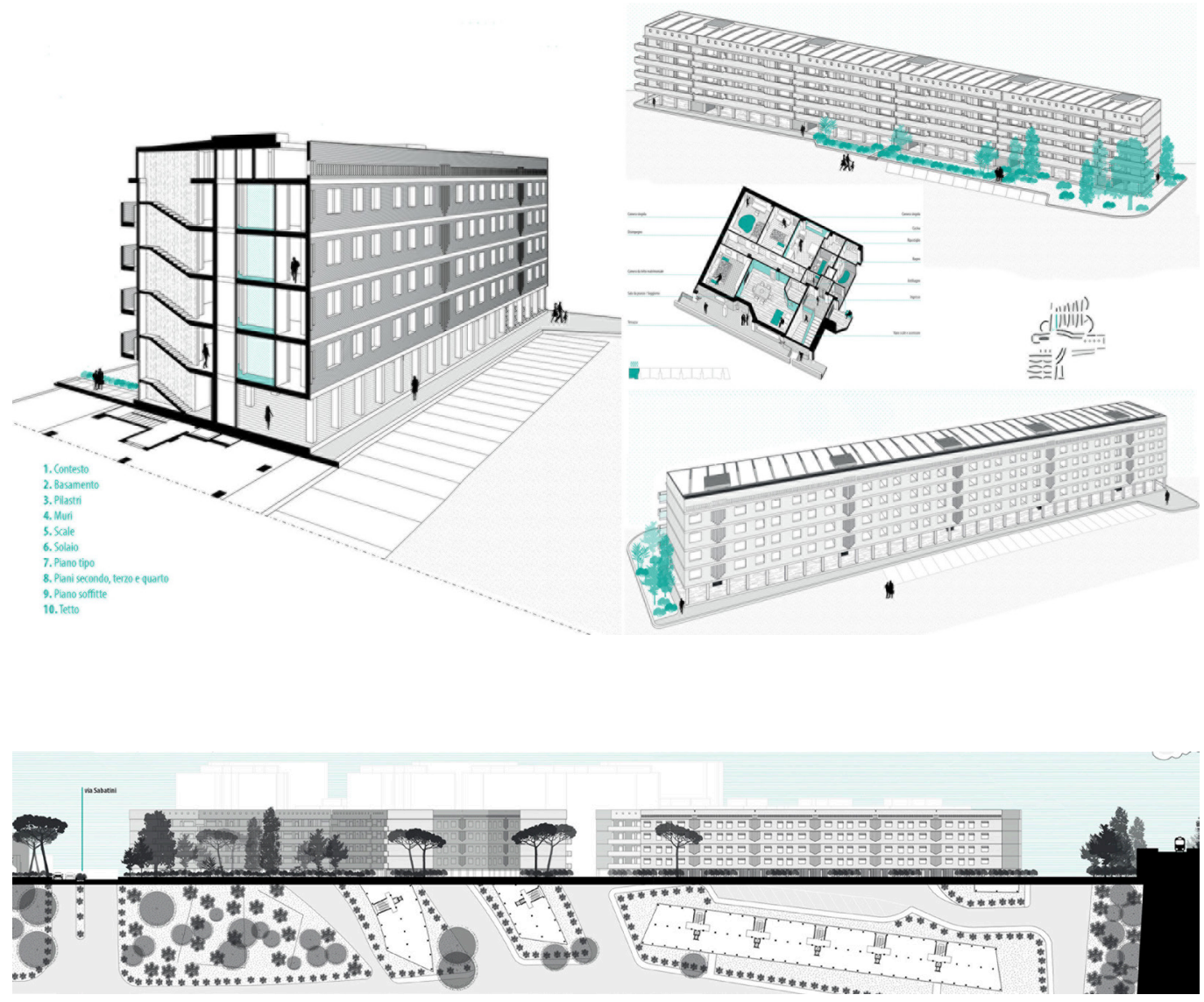
Fig. 10. Current views of the neighborhood where the sinuous shapes of the buildings are highlighted, which generate concave and convex spaces. coherent language, defined by common elements, uniformed by the use of the pilotis from the spaces used in a functional way [Talamona 20 I0, pp. 3/3-327].

The appreciation of the French master had a great prominence and probably encouraged the solutions of the urban plan for the INCIS Decima district, drawn up in those years by Moretti himself with Libera, Cafiero and Ignazio Guidi, in which the system of pilotis and road systems is proposed again, hieratically organized to serve common spaces and greenery, intended as a system of relationship for the inhabitants.
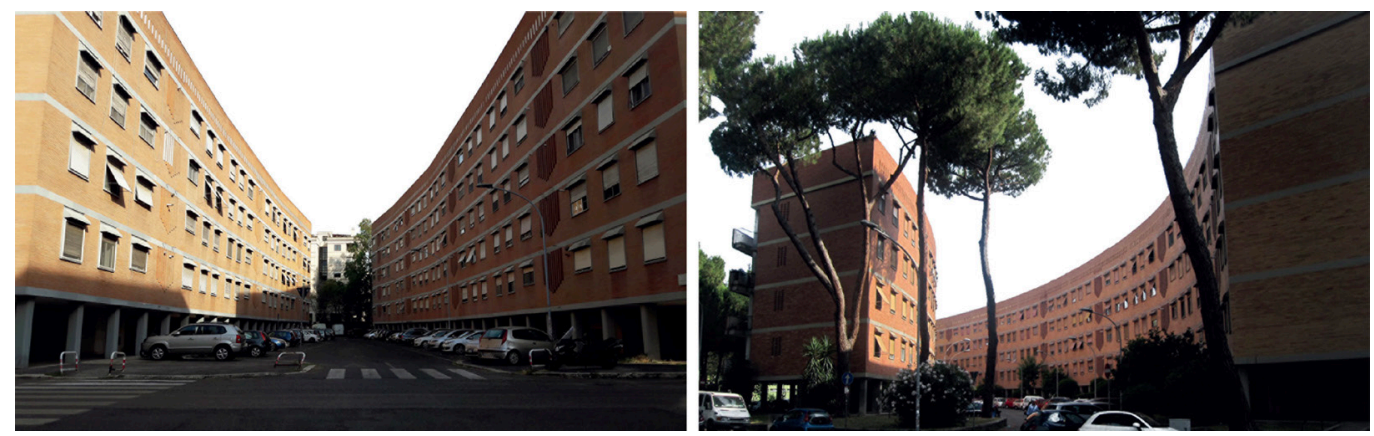

\section{INCIS Decima tenth district. The design intentions}

Decima was born in a fortunate historical period. In the midst of the economic boom and as anticipated in the wake of the 1960 Olympics that had led to the construction of the homonymous Village. For both districts, the body that financed the works plays a fundamental role, the INCIS which addresses the middle class with the construction of housing for the use of state employees and their families, offering higher standards and comfort than those of public housing, promoted by the IACP. The location of the aforementioned districts is in this sense privileged since, despite affecting peripheral areas, are located near the large management centers, in the Flaminio and E.U.R. [Moretti 1962, pp. I09- I I5].

In those years it had focused on the expansion south of the capital, considering the development of the E.U.R. and the desire to go towards the sea following the course of the Tiber. In this sense, the variant of the 1962 Regulatory Plan provides for the construction of new residential centers in the southern area, in which the Decima district is located, inserted on the layout of the Rome-Ostia Lido metropolitan railway.

Luigi Moretti assumes the general coordination of the urban plan and considers the neighborhood an opportunity to experiment with his theories on living; therefore he imagines it as a housing complex in which he himself could have lived, identifying himself with the needs of users.

The area is completely modeled to meet the needs of users starting from the road system set on three levels with differentiated heights, from the fast-moving inter-district axis given by the extension of the Via Olimpica ( $13 \mathrm{~m}$. sim), to the intra-road system, to the pedestrian areas and related spaces for children, schools and kindergartens (8 m. sim).

The different levels were connected, but independent of each other to ensure that the district driveways could, if necessary, pass under the large inter-neighborhood artery, the pedestrian streets in turn were inserted under the carriageways creating passages in complete safety without vehicular crossings.

A road system organized to accommodate the modern lifestyle of the inhabitants, based on contemporary everyday life in which almost all families owned at least one car, in which there was the need to have sufficient parking spaces, designed with an urban layout that provided for a clear separation of flows. 
The dynamics have been studied to connect and to create cohesion between the residents, Moretti has a clear understanding of the difference between the space of the individual and the space of the community. The idea is to give life to a neighborhood that favors the concept of neighborhood with a social role that materializes through precise urban and architectural choices.

The examination of the project tables and the 'sketches' developed by Moretti allow us to understand the innovative value of the proposed intervention. The choice of the typologies, their arrangement in relation to the greenery, conceived as a continuous element that through the 'emptying' of the ground floor of the buildings, the arcades with the pilotis, visually connects the whole neighborhood. A visual fluidity that flows and expands in the "valleys" obtained between the enveloping and shapes of the buildings. The term 'vallette' is specially designed by the architect to define the green spaces located in the convexities or concavities generated by the buildings, as distinctive elements with respect to the other green spaces in the district.

Fig. I I. Current views of the neighborhood where the perspective views generated by the buildings are highlighted, the green and driveways, the attention to materials and architectural details.
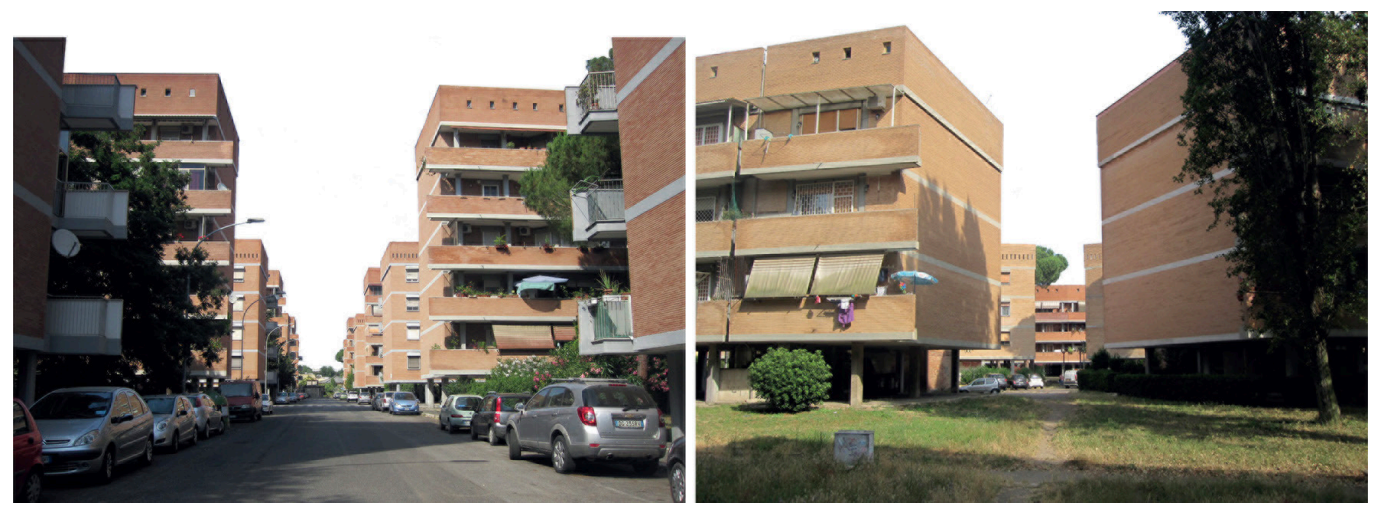

\section{Analysis of the actual state: differences, transformations, critical issues}

Examining the actual state, a series of differences were found with respect to the original project, some concern the unrealized works: 39 residential buildings compared to the 53 designed which exclude the 6 houses in line with 4 and 5 floors, the house in line with 12 semicircular planes, the three 14-story lenticular towers and the four 13-storey cruciform towers.

The neighborhood has also been deprived of common spaces such as the round fountain, places designed for children to play and services: kindergartens, schools, the shopping center and the Church. For the failure to build the church, of which a perspective view of the interior and some sketches remains, it is important to consider the correlations with the theoretical reflections, proposed by the inventor in the same years, on sacred spaces. In 1962 in a conference entitled Spazi - Luce nell'architettura religiosa, Moretti proposed an extraordinary excursus on the role of light in sacred architecture, ranging from the Pantheon to eighteenth-century churches. The study of the and shapes elaborated for Sancta Maria Mater Ecclesiae and Decima find clear evidence with the meteorological coherence and scientific research on the theme that starts from the ancient to arrive at the definition of an enveloping space as required by the council reform. Failure to do so does not allow for material feedback, the studies conducted on the subject and the need, indicated in the project and felt by the inhabitants, for the presence of a sacred place where the community could meet which subsequently led to the creation of a small prefabricated church remain. Returning to the discrepancies, analyzed with reconstructive hypotheses conducted and represented through digital models compared with the current realty, the transformations were highlighted, in particular the road transformations that conditioned the systems of the public space and green area, jeopardizing the levels of viability that, as described, constituted 
a nodal point of the project. In the graphical analysis, it is possible to observe the relationship between the original and the current roads, the central axis appears today congested by traffic that has compromised the internal pedestrian traffic and the original use of green spaces. The abolition of the 7 tower types that stood out the ideal continuation of the Via Olimpica highlighting the district reduced the visual and conceptual link with the Olympic Forum and the E.U.R. Other critical issues are attributable to the transformations produced by successive expansions which, with their intensive development, have incorporated the surrounding fabric. The Torrino district has extended into the Decima area taking some portions, as in the case of the secondary school 'Matteo Ricci', built to meet the urban planning standards of the new settlement, instead of the expected and unrealized body of water.

The school is an emblematic case, sine the architectural quality of the building is definitely questionable and does not relate to the district housing concepts.

\section{Conclusions}

Over the years, the stratifications have been multiple; the area plan has occupied the urban voids left by the failure to implement the project for Decima, unfortunately weakening the matrix of the district itself which has become a passageway where few recognize the architectural value. The investigations conducted on the original project revealed the transformations and the critical issues, referring them to the intentions that Moretti had for this area, a housing area model gradually reduced in size, but preserves its connotations in the system. The results achieved with the graphic analyzes, the connections between the theoretical concepts and the operative choices made by the designer, conducted through the drawing and the digital reconfigurations [I], indicate the direction for a possible requalification, dictated by the same design assumptions. In conclusion, the analysis carried out directs the reorganization of relations between public spaces and the inhabited area, between the district and its surroundings, taking inspiration from new connections such as that of the next construction of the stadium Tor di Valle which constitutes an opportunity for the rebirth of Decima which, if not exploited, will lead to further urban and social compression. The space_ and shape_structure connections sought by Moretti can still define links; generate mending between the neglected suburbs, in the specific case of the author, and the new urban polarities.
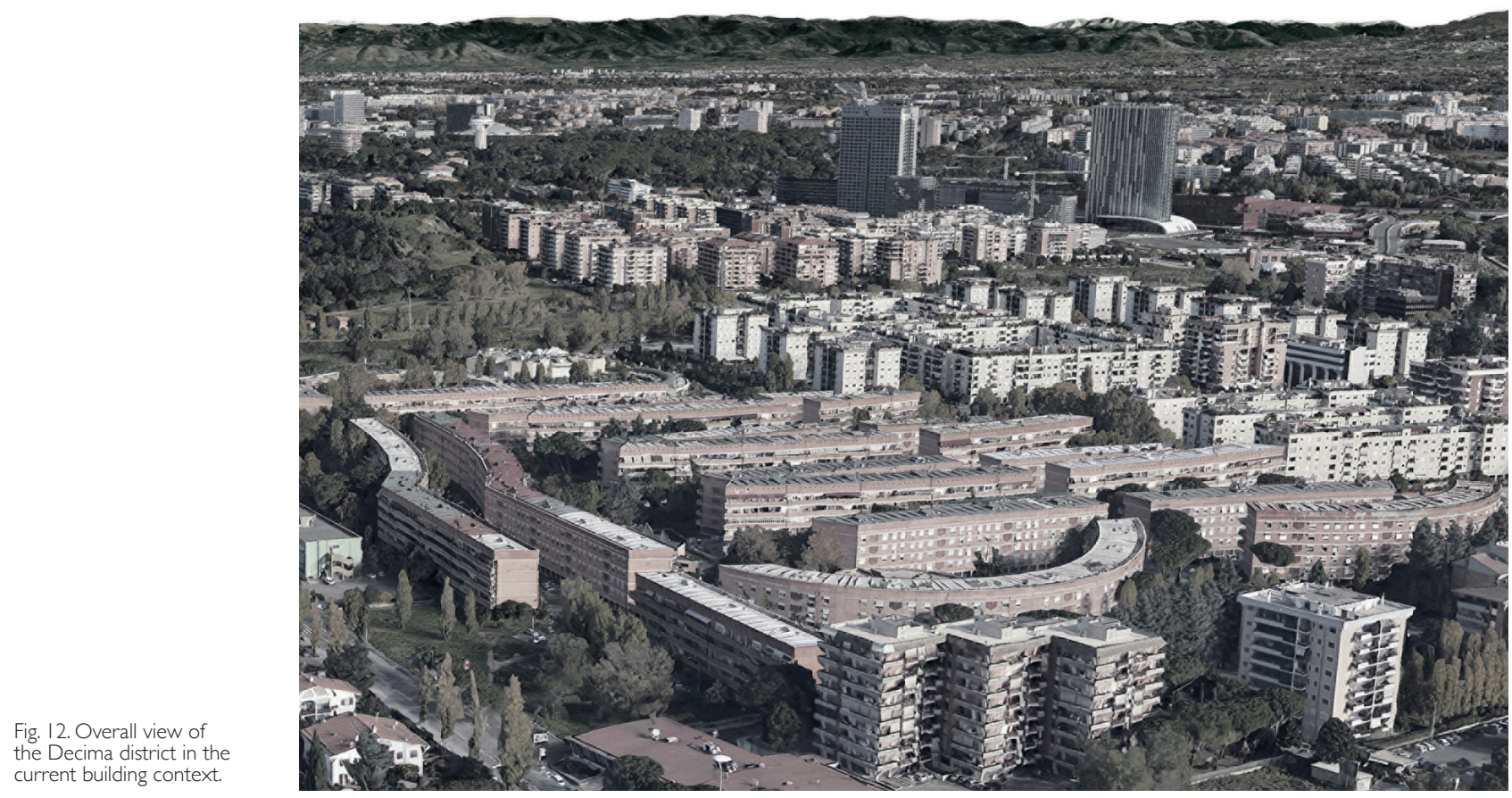


\section{Notes}

[I]The research was carried out with the collaboration of Celeste D'Ercoli.

\section{References}

Bozzoni Corrado, Fonti Daniela, Muntoni Alessandra (2012). Luigi Moretti. Architetto del Novecento. Roma: Gangemi Editore. Bucci Federico, Muzzalani Marco (2000). Luigi Moretti. Opere e scritti. Milano: Electa.

Casciato Maristella,Viati Navone Annalisa (20 I 0). Luigi Moretti architetto. Dal razionalismo allinformale. Guida alla Mostra MAXXI 30 maggio-28 novembre 2010. Milano: Electa.

Cuzzer Anna, Cordella Giovanni, Bertuglia Cristoforo (20l0). Testimonianza. Ricordi dell'IRMOU. In Reichlin Bruno, Tedeschi Letizia (a cura di). Luigi Moretti, Razionalismo e trasgressività tra barocco e Informale. Milano: Electa, pp. 43I-35.

Fabiani Roberto (1966). Decima: quartiere sereno. In Capitolium, n. I, gennaio, pp. 40-45.

Finelli Luciana (2005). Luigi Moretti. La promessa e il debito. Architetture 1926-1973. Roma: Officina edizioni.

Moretti Luigi (1954). Structure comme forme, in Spazio, n. 6, pp. 5- 12.

Moretti Luigi (1962). Nuovo quartiere Incis, nella zona EUR. in La Casa, 1962, n. n7, pp. $109-122$.

Moretti Luigi (197I). Ricerca matematica in Architettura e Urbanistica. In Moebius, n. I, pp. 30-53.

Rostagni Cecilia (2008). Luigi Moretti 1907-1973. Milano: Electa.

Reichlin Bruno, Tedeschi Letizia (20 I0). Luigi Moretti. Razionalismo e trasgressività tra barocco e Informale. Milano: Electa.

Rossi Piero Ostilio (2012). Guida all'architettura moderna 1909-201 I. Roma-Bari: Laterza.

Spinelli Luigi (2012). Gli spazi in sequenza di Luigi Moretti. Siracusa: Lettera Ventidue.

Santuccio Salvatore (1986). Luigi Moretti. Bologna: Zanichelli.

Talamona Marida (20I0). II Villaggio olimpico. In Reichlin Bruno, Tedeschi Letizia (a cura di). Luigi Moretti. Razionalismo e trasgressività tra barocco e informale. Milano: Electa, pp. 313-327.

Tedeschi Arturo (2014). AAD Algorithms-Aided Design. Parametric strategies using grasshopper. Brienza: Le Penseur.

\section{Author}

Caterina Palestini, Università degli Studi dell'Adriatico "G. d'Annunzio" Chieti- Pescara, palestini@unich.it

To cite this chapter. Palestini Caterina (2020). Connessioni spazio_forma_struttura. : Le teorie dell'abitare di Luigi Moretti, analisi e riconfigurazioni del quartiere Decima a Roma/Connections space_shape_structure. Luigi Moretti's theories of living, analysis and reconfigurations of the Decima District in Rome. In Arena A., Arena M., Brandolino R.G., Colistra D., Ginex G., Mediati D., Nucifora S., Raffa P. (a cura di). Connettere. Un disegno per annodare e tessere. Atti del $42^{\circ}$ Convegno Internazionale dei Docenti delle Discipline della Rappresentazione/Connecting. Drawing for weaving relationships. Proceedings of the 42th International Conference of Representation Disciplines Teachers. Milano: FrancoAngeli, pp. I276- I295. 